\title{
Indicators of Energy Efficiency in Buildings. Comparison with Standards in Force in Argentina
}

\author{
María Belén Salvetti", Jorge Czajkowski, Analía Fernanda Gómez \\ Laboratorio de Arquitectura y Hábitat Sustentable (LAyHS), \\ Facultad de Arquitectura y Urbanismo, Universidad Nacional de La Plata, \\ La Plata, Argentina \\ Email: *salvetti_belen@hotmail.com,jdczajko@gmail.com, afgomez2001@yahoo.com.ar \\ Received August 15, 2013; revised September 20, 2013; accepted October 1, 2013
}

Copyright (C) 2013 María Belén Salvetti et al. This is an open access article distributed under the Creative Commons Attribution License, which permits unrestricted use, distribution, and reproduction in any medium, provided the original work is properly cited.

\begin{abstract}
In this work we make a comparative study of the energy behaviour in different building types. We analyze three cases of office buildings and three residential buildings, and compare them with a previous sample. We seek to find correlations or differences in behavior in terms of potential energy losses and gains, and UL values compared with Argentinian Standards to verify the degree of efficiency. For energy analysis we used a software which allows the analysis of thermal and energy building performance at steady state on a monthly basis. This software is called EnergoCAD and it also determines formal indicators based on IRAM standards. We conclude that the indicators used are clear to energetically "grade" buildings and to facilitate comparisons. In turn, smaller buildings are relatively less energy efficient than larger ones. At the same time it is noteworthy that the energy inefficiency has been growing rapidly over the years. Finally it is noted that none of the cases analyzed meets the National Standards.
\end{abstract}

Keywords: Energy Efficiency; Buildings; Standards; Indicators

\section{Introduction}

The following work was developed in LAyHS-FAUUNLP. It is framed within one of the main research lines developed in the laboratory, aimed at energy efficiency in building for urban areas. It is part of the objectives of PICT 06\#956 "Energy efficiency in building for metropolitan areas" and of the project accredited by UNLP "Energy Efficiency and Sustainability for the materialization of Buildings in the Context of Climate Change Adaptation."

The importance of this topic is related to two current issues: scarcity of resources and global warming. As far as is known, these two problems are responsible for the environmental deterioration that the world has been suffering, in which architecture and urban construction have a significant degree of influence [1].

For a long time we have relied on the development of appropriate technologies for the management of largescale natural resources so that it is possible to meet the needs of the population. However, nowadays we can see this is not true because resources have been exhausted

\footnotetext{
${ }^{*}$ Corresponding author.
}

and the risk that this entails for the lives of millions of people and for the environment is growing [2].

The rapidly growing world energy use has already raised concerns over supply difficulties, exhaustion of energy resources and heavy environmental impacts (ozone layer depletion, global warming, climate change, etc.). The International Energy Agency has gathered frightening data on energy consumption trends. During the last two decades (1984-2004), primary energy has grown by $49 \%$ and $\mathrm{CO} 2$ emissions by $43 \%$, with an average annual increase of $2 \%$ and $1.8 \%$ respectively. Current predictions show that the growing trend will continue [3].

The construction industry is one of the most important consumers of raw materials and non-renewable resources, and represents an important source of contamination during the different phases in the life cycle of a building. This implies a significant environmental impact not only during the process of extraction and processing of raw materials, but also during the construction and actual use of buildings, and also later when the building is demolished and recycled [4].

Fossil fuels are the main source of energy used in 
buildings. In Argentina, for instance, $96 \%$ of power generation is through combined cycle while natural gas is intensively used for heating [5]. The scarcity and the potential risk posed by carbon emissions, generated by their use, make it necessary to discuss such intensive employment.

Building energy efficiency has come to the forefront of political debates due to high energy prices and climate change concerns. Improving energy efficiency in new commercial buildings is one of the easiest and lowest cost options to decrease a building's energy use, owner operating costs, and carbon footprint. Conventional energy efficiency technologies such as thermal insulation, low-emissivity windows, window overhangs, and day lighting controls can be used to decrease energy use in new commercial buildings by $20 \%-30 \%$ on average and up to over $40 \%$ for some building types and locations [6].

In Europe there are numerous examples of sustainable construction which are aware of the current problems of scarcity of resources. Every day several print media, specializing in architecture, show more examples of corporate buildings that seek to improve their image by appealing to sustainable design. It is appropriate to take advantage of this growing wave of interest in the environment which is gaining ground in the field of construction, to develop buildings that are not only efficient in energy consumption, but also show respect for the environment.

The last seventy years of urban architecture history in Argentina show the emergence and development of buildings that grew on the constraints of urban sites. Building codes supported growth in height, increasing the profitability of soil [7]. However, during the period from 1900 to 1990 , the thermal quality of buildings, especially the residential ones, went down despite growing technology offering. On the other hand, although the standards of buildings" thermal quality that have existed since the late " $70 \mathrm{~s}$, private production has never ceased to lower quality standards to the point that in 1986 a revision of the Argentine standards was approved further lowering quality requirements" [8].

In recent years there has been progress in building energy efficiency indicators for tower blocks. In Argentina there already exist standards on energy saving in heating and cooling of residential buildings. They are IRAM 11659-2 [9] and IRAM 11604 [10]. However, there is the need for an antecedent for other uses such as office buildings, in public or private. There has not been a consensus in the country as to which is an appropriate efficiency indicator to hold energy demand and move towards "low energy" or "zero energy" building proposals.

\section{Objective}

The aim of this paper is to make a comparative analysis of the energy performance in different cases, both residential buildings and office ones, taking into account the many variables needed for its realization.

\section{Materials and Methods}

To carry out the work we took a sample of six buildings, three homes and three offices, with different structural characteristics. The choice of examples was randomly selected from various print media specializing in architecture. The intention was that the various examples chosen presented diverse forms of window and facade design, in terms of glazed surfaces and opaque walls, in solar protection systems, among others.

At the same time a previous work [11] was taken as part of the sample for a comparative analysis (see Table 1).

Table 1. Summary table previous sample.

\begin{tabular}{cccccccc}
\hline Building & Envelope area $\left(\mathrm{m}^{2}\right)$ & Building area $\left(\mathrm{m}^{2}\right)$ & Volume $\left(\mathrm{m}^{3}\right)$ & Form Factor & $\mathrm{CLF}\left(\mathrm{W} /{ }^{\circ} \mathrm{C}\right)$ & $\mathrm{Q}_{\text {heating }}(\mathrm{kWh} /$ year $)$ & $\mathrm{Q}_{\text {heating }}\left(\mathrm{kWh} / \mathrm{m}^{2} /\right.$ year $)$ \\
Comega & 19,045 & 13,357 & 40,071 & 0.48 & 4.00 & 909,212 & 68 \\
Chacofi & 16,975 & 10,736 & 32,208 & 0.52 & 4.23 & 972,647 & 91 \\
Conurban & 22,776 & 15,118 & 45,354 & 0.50 & 4.14 & $1,377,589$ & 91 \\
Esmeralda 116 & 9358 & 26,555 & 79,666 & 0.12 & 4.14 & $1,966,292$ & 74 \\
IBM & 32,612 & 18,067 & 54,201 & 0.60 & 6.48 & $1,799,576$ & 100 \\
Libertad 565 & 3848 & 1323 & 3970 & 0.97 & 3.64 & 213,527 & 161 \\
Madero & 24,153 & 25,142 & 75,426 & 0.32 & 4.77 & $1,815,493$ & 72 \\
Malecom & 8761 & 5045 & 15,136 & 0.58 & 4.16 & 532,326 & 106 \\
Corrientes 1427 & 7451 & 4219 & 12,656 & 0.59 & 4.48 & 403,810 & 96 \\
Libertad 731 & 7582 & 56,191 & 16,858 & 0.45 & 2.52 & 544,560 & 97 \\
La Plata & 14,479 & 12,681 & 38,043 & 0.38 & 4.20 & $1,018,820$ & 80 \\
\hline
\end{tabular}


Once the sample was taken, the characteristics of the envelope were determined from the graphic data and technical reports of the buildings. At the same time the formal design analysis was deepened in the different examples and their relation to the thermal quality of buildings, and the rational use of energy among other aspects.

For energy analysis we used the software EnergoCAD [12]. This software allows the analysis of thermal and energy building performance at steady state on a monthly basis. It also determines formal indicators based on IRAM standards. Then the results are exported to Excel for statistical analysis.

We proceeded with the completion of synthesis forms (Figures 1-6), which contain all the basic information of the case studies to its use with different graphics.

\section{Results}

As a result of the information processing we obtained the following results, which can be grouped as follows:

\subsection{Office Building}

We took three examples of office buildings (Figures 1-3)

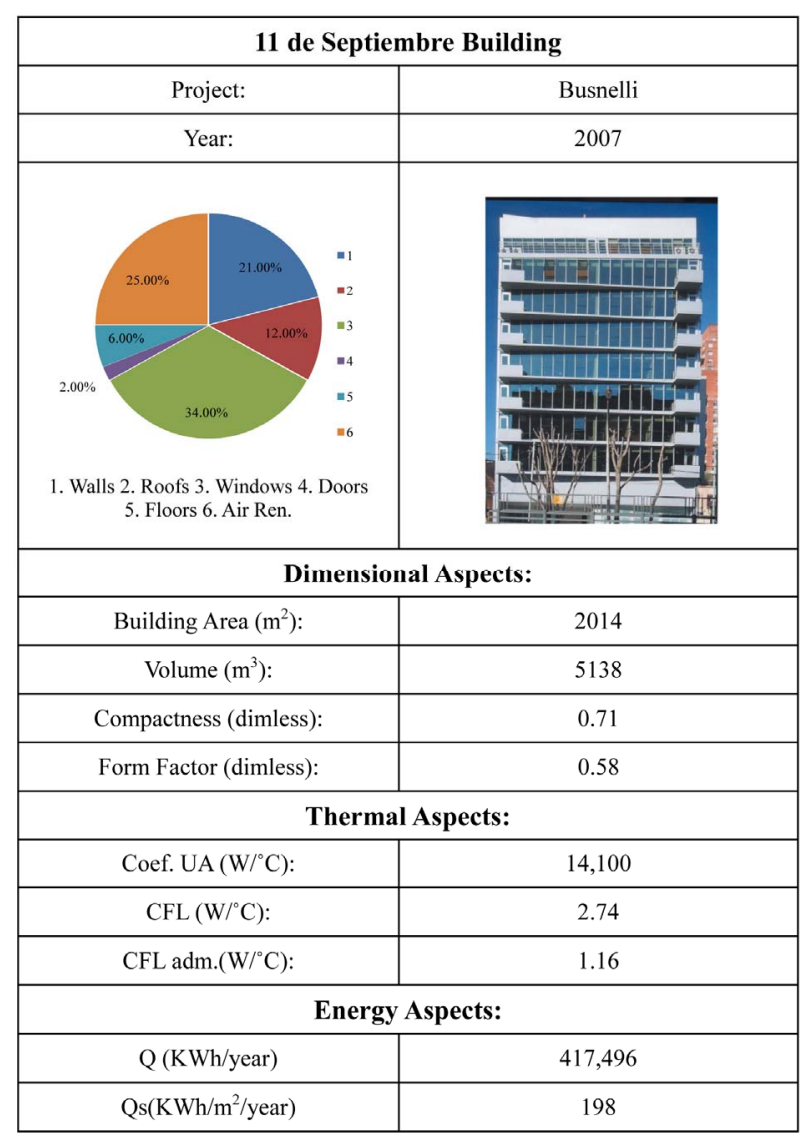

Figure 1. Basic description of 11 de Septiembre building (dimensional aspects, thermal aspects and energy aspects).

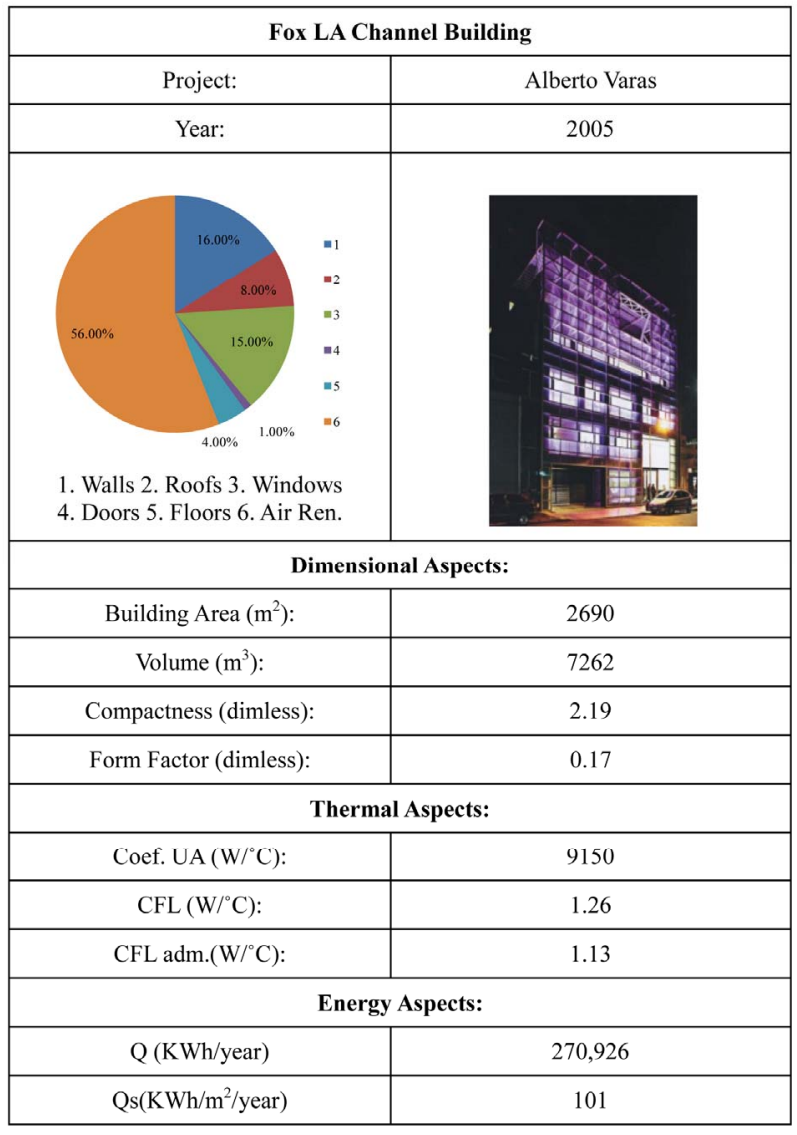

Figure 2. Basic description of Fox LA Channel building (dimensional aspects, thermal aspects and energy aspects).

with different structural characteristics. They have different fenestrations, facade treatment, opaque and glazed surfaces, solar protection, etc.

\subsection{Apartment Building}

In this instance three cases of residential buildings were taken as examples (Figures 4-6), which also, as in previous cases, have different structural characteristics, have different fenestrations, opaque and glazed surfaces, sun protection, etc.

Figure 7 shows the relationship between the volume to be air conditioned and the heat load of the buildings analyzed in this study. There is a big difference in dimensions between the ANSES building (Figure 3) and the rest of the buildings discussed, as well as the heat load required for air conditioning it.

For its part, Figure 8 shows the relationship between the volume to be heated and the heat load of the buildings analyzed, and it compares them with the buildings of a previous work. The trend lines for each of the works are similar.

$$
\mathrm{Q}_{\text {heating }}=39.749 \times \text { volume }+139849(\mathrm{KWh} / \text { year })
$$




\begin{tabular}{|c|c|}
\hline \multicolumn{2}{|c|}{ ANSES Building } \\
\hline Project: & M SG S S V \\
\hline Year: & 1974 \\
\hline $\begin{array}{l}\text { 5.500\% } \\
\text { 1. Walls 2. Roofs 3. Windov } \\
\text { 4. Doors 5. Floors 6. Air Re }\end{array}$ & 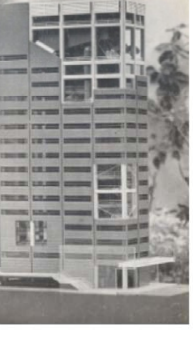 \\
\hline \multicolumn{2}{|c|}{ Dimensional Aspects: } \\
\hline Building Area $\left(\mathrm{m}^{2}\right)$ : & 12,784 \\
\hline Volume $\left(\mathrm{m}^{3}\right)$ : & 42,389 \\
\hline Compactness (dimless): & 1.15 \\
\hline Form Factor (dimless): & 0.26 \\
\hline \multicolumn{2}{|c|}{ Thermal Aspects: } \\
\hline Coef. UA $\left(\mathrm{W} /{ }^{\circ} \mathrm{C}\right)$ : & 62,006 \\
\hline $\operatorname{CFL}\left(\mathrm{W} /{ }^{\circ} \mathrm{C}\right):$ & 1.46 \\
\hline $\mathrm{CFL}$ adm. $\left(\mathrm{W} /{ }^{\circ} \mathrm{C}\right):$ & 1.11 \\
\hline \multicolumn{2}{|c|}{ Energy Aspects: } \\
\hline $\mathrm{Q}(\mathrm{KWh} /$ year $)$ & $1,835,917$ \\
\hline $\mathrm{Qs}\left(\mathrm{KWh} / \mathrm{m}^{2} /\right.$ year $)$ & 144 \\
\hline
\end{tabular}

Figure 3. Basic description of ANSES building (dimensional aspects, thermal aspects and energy aspects).

$$
\mathrm{Q}_{\text {heating }}^{\prime}=23.788 \times \text { volume }+155940(\mathrm{KWh} / \text { year })
$$

The steeper slope of the term (1), which corresponds to cases of recent construction, shows a growth in energy demand for heating, which adds to the energy inefficiency in recent years.

Among the cases analyzed in this work, two are prominent: the LAChannel Fox building (Figure 3) and the ANSES building (Figure 4). The first one is below the trend line (Figure 8), while the second one has values above the rest. Additionally, the latter can also be compared to the $I B M$ building (Table 1). The volume to be heated in the IBM building is higher than in the ANSES one, however the heat loads are similar.

Figure 9 shows the heat load per square meter for the different cases analyzed. The sector " $A$ " distinguishes those buildings to be climate-controlled with a volume less than three thousand cubic meters. These provide a wide variation in the heat load per square meter. Our hypothesis is that smaller buildings involve heating systems which do not impact significantly on the initial cost and show less concern for energy conservation. For their part, the buildings with a greater volume than three thousand cubic meters show a correlation with the nega-

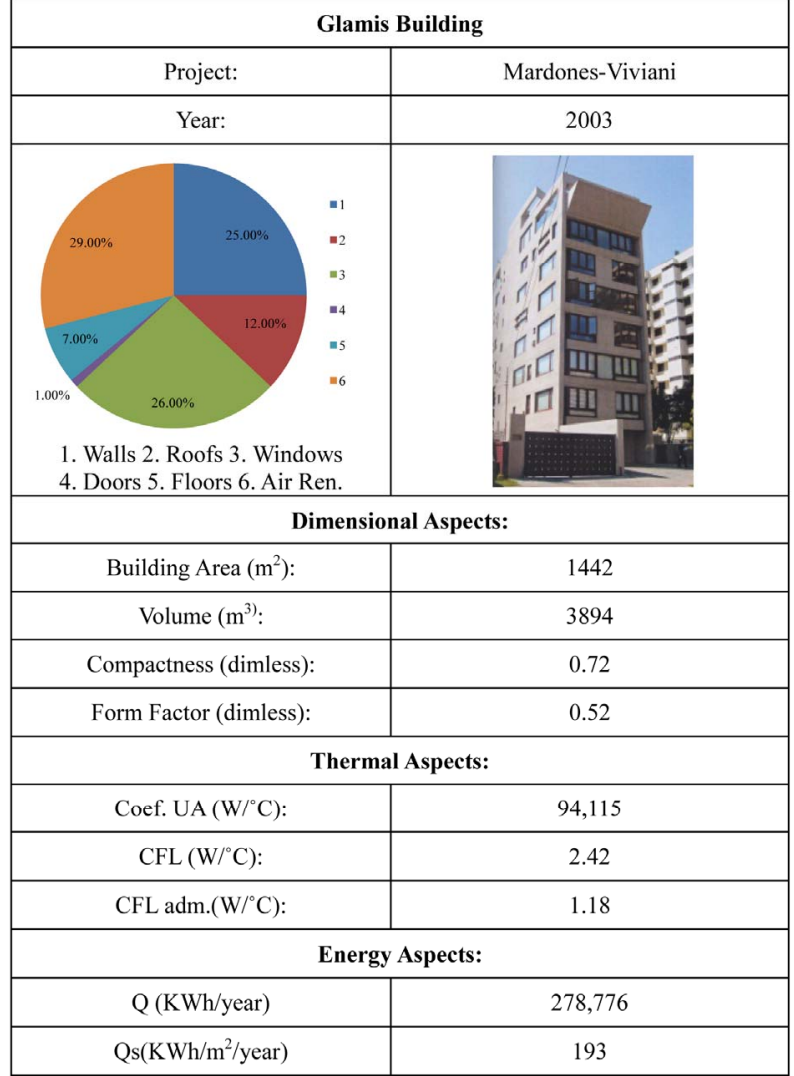

Figure 4. Basic description of Glamis building (dimensional aspects, thermal aspects and energy aspects).

tive slope, where the heat load per square metre increases as the size of the building decreases.

Figure $\mathbf{1 0}$ in turn relates the volume of different buildings with their Global Heat Loss Coefficient (UL) $\left[\mathrm{W} / \mathrm{m}^{3}{ }^{\circ} \mathrm{C}\right]$. It can be seen as in all cases that the $U L$ of the building exceeds the allowable $U L$, consequently there are no cases of present or previous building samples which comply with unbinding Argentina standard IRAM 11604. The correlation between the heated volume and the $U L$ is low in the current sample $(\mathrm{R} 2=0.352)$ and in the previous sample it is even lower $(\mathrm{R} 2=0.195)$. This shows the lack of regulation of buildings' energy quality in Building Codes in Argentina. Moreover, in the current sample the relationship glazed/opaque is lower than in office towers of the previous sample, and this leads the UL to be significantly lower and closer to the allowable values of the IRAM standards.

\subsection{Comparison among Deployed Buildings in Intermediate Cities in Temperate Climates}

We performed an analysis which aims to show the energy performance of different buildings in some of the most important cities of Argentina (Table 2), with different weather characteristics, but all within the temper- 
Table 2. Summary table of the cities analyzed.

\begin{tabular}{cccc}
\hline City, Province & Latitude $\left({ }^{\circ}\right)$ & Size (population $\left.{ }^{*}\right)$ & Heating Degree Days $\left({ }^{\circ} \mathbf{C}^{* *}\right)$ \\
\hline Paraná, Entre Rios & -39.80 & 237,000 & 591 \\
Córdoba, Córdoba & -31.40 & $1,316,000$ & 608 \\
La Plata, Buenos Aires & -35.00 & 563,000 & 992 \\
Bahía Blanca, Buenos Aires & -38.70 & 318,000 & 1369 \\
Mar del Plata; Buenos Aires & -38.10 & 542,000 & 1653 \\
\hline
\end{tabular}

${ }^{*}$ INDEC 2001, ${ }^{* *}$ IRAM $11603\left(18^{\circ} \mathrm{C}\right)$.

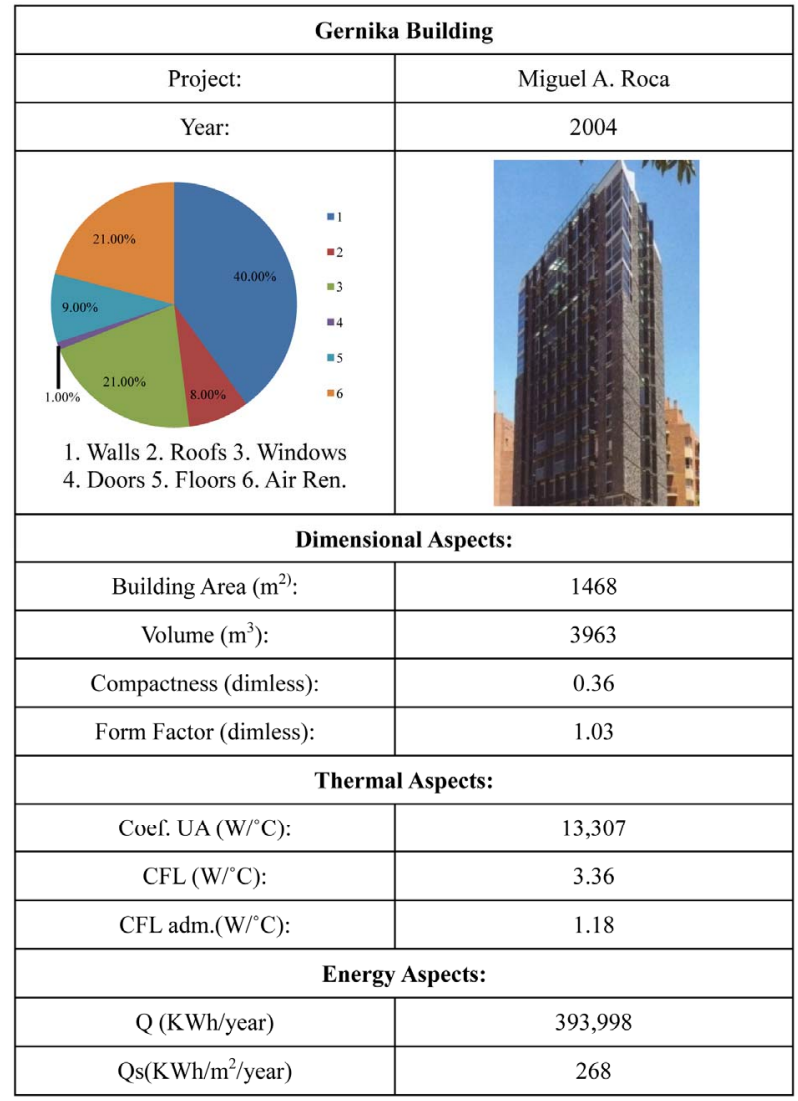

Figure 5. Basic description of Gernika building (dimensional aspects, thermal aspects and energy aspects).

ate/mesothermal climate (Group C), [13].

Figure 11 shows the energy performance of the Gernika building (Figure 6), and its annual gains and losses according to different cities of Argentina.

It can be seen that in the case of Córdoba city $\left(31^{\circ} 21^{\prime} \mathrm{S}\right.$, $64^{\circ} 05^{\prime} \mathrm{W}$ ) the building shows the possibility of making gains of approximately 2,000,000 kWh/year, far higher than what could be obtained in other locations.

In most cases, the losses do not reach $500,000 \mathrm{kWh} /$ year, marking an important difference between both values, while in other cities like La Plata $\left(34^{\circ} 55^{\prime} \mathrm{S}, 57^{\circ} 57^{\prime}\right.$ W), Mar del Plata ( $\left.38^{\circ} 00^{\prime} \mathrm{S}, 57^{\circ} 33^{\prime} \mathrm{W}\right)$ and Bahía Blanca

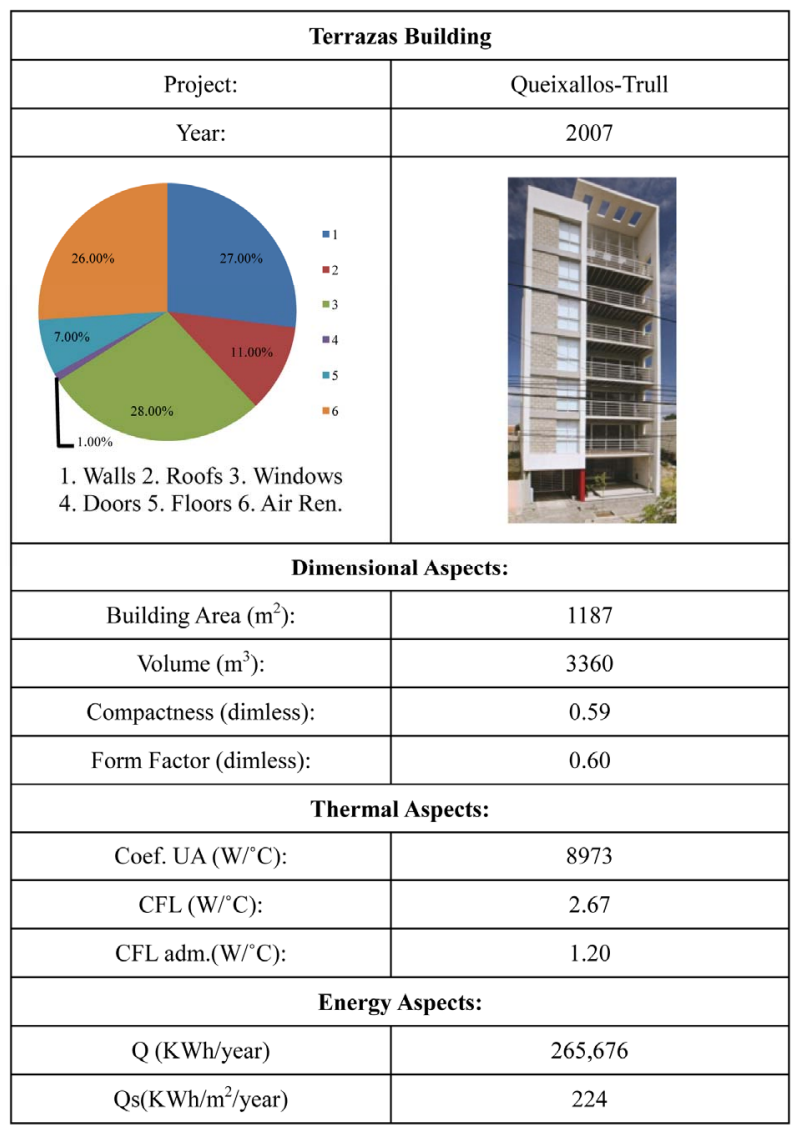

Figure 6. Basic description of Terrazas building (dimensional aspects, thermal aspects and energy aspects).

$\left(38^{\circ} 44^{\prime} \mathrm{S}, 62^{\circ} 16^{\prime} \mathrm{W}\right)$ the gains and losses do not differ greatly. However, this is not the case with Paraná $\left(31^{\circ} 44^{\prime}\right.$ $\mathrm{S}, 60^{\circ} 32^{\prime} \mathrm{W}$ ); for this location, the percentage of annual heat loss is lower than in the other cities examined, and the potential gains are not as important as in the case of Córdoba $\left(31^{\circ} 21^{\prime} \mathrm{S}, 64^{\circ} 05^{\prime} \mathrm{W}\right)$.

For its part, Figure 12 shows the energy performance of the ANSES building (Figure 4). When located in La Plata city $\left(34^{\circ} 55^{\prime} \mathrm{S}, 57^{\circ} 57^{\prime} \mathrm{W}\right)$ the building heat losses are approximately $1,800,000 \mathrm{kWh} /$ year while heat gains fall short of $1,000,000 \mathrm{kWh} /$ year. Contrary to what happens in Córdoba $\left(31^{\circ} 21^{\prime} \mathrm{S}, 64^{\circ} 05^{\prime} \mathrm{W}\right)$ and Paraná $\left(31^{\circ} 44^{\prime} \mathrm{S}\right.$, 


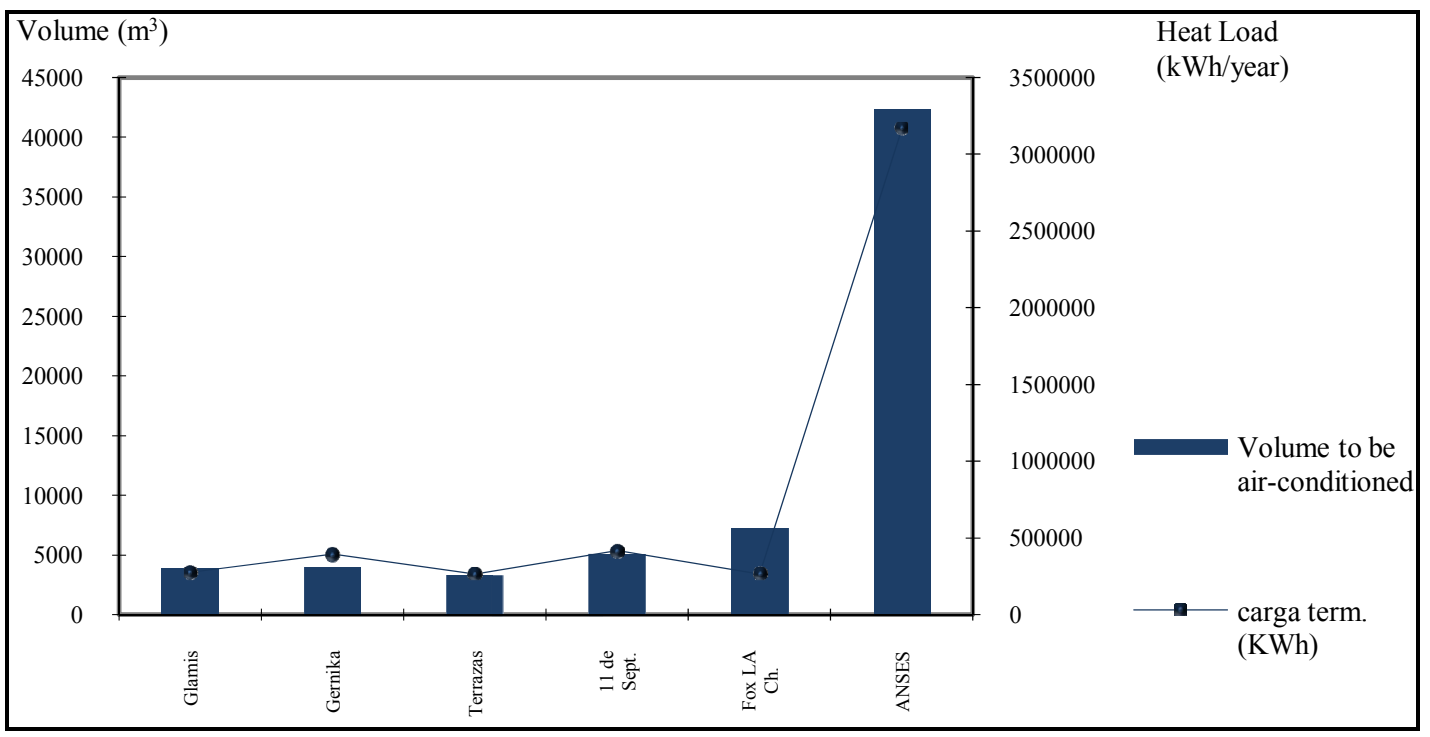

Figure 7. Relationship between the volume to be heated up/cooled and the heat load. Synthesis.

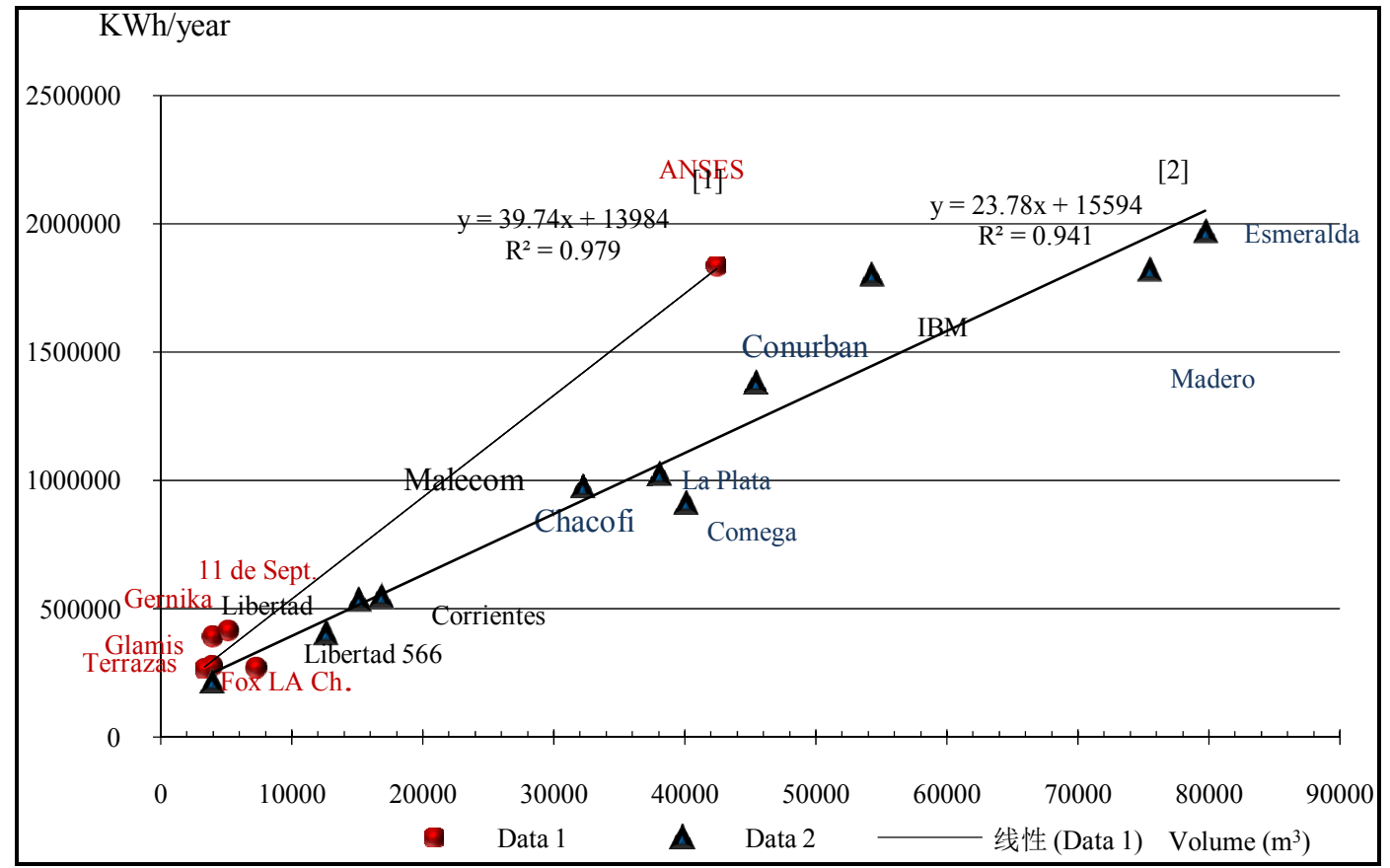

Figure 8. Relationship between the heated volume and the annual heat load. Comparison with previous work.

$\left.60^{\circ} 32^{\prime} \mathrm{W}\right)$ where the building has a balance of heat losses and gains, for the cities of Mar del Plata $\left(38^{\circ} 00^{\prime} \mathrm{S}, 57^{\circ} 33^{\prime}\right.$ $\mathrm{W})$ and Bahía Blanca $\left(38^{\circ} 44^{\prime} \mathrm{S}, 62^{\circ} 16^{\prime} \mathrm{W}\right)$ the number of heat losses is far greater than the potential gains.

\section{Conclusions}

In this work we made a comparative analysis of different buildings and their energy performance. We could observe the relationship between the heat loads required to heat up/cool a building and its volume. To conclude with a hypothesis we can state that the smaller buildings show less concern for energy savings; these buildings involve heating systems that do not impact significantly on the initial cost. In turn, in buildings with a volume greater than three thousand cubic meters we observed that as the size of the building increases, the heat load decreases.

The analysis of individual cases and the comparison with the previous sample showed the growth in energy demand for heating in recent years, which implies an increase in energy inefficiency.

At the same time, we studied the energy behavior of a building for different cities with diverse weather charac- 


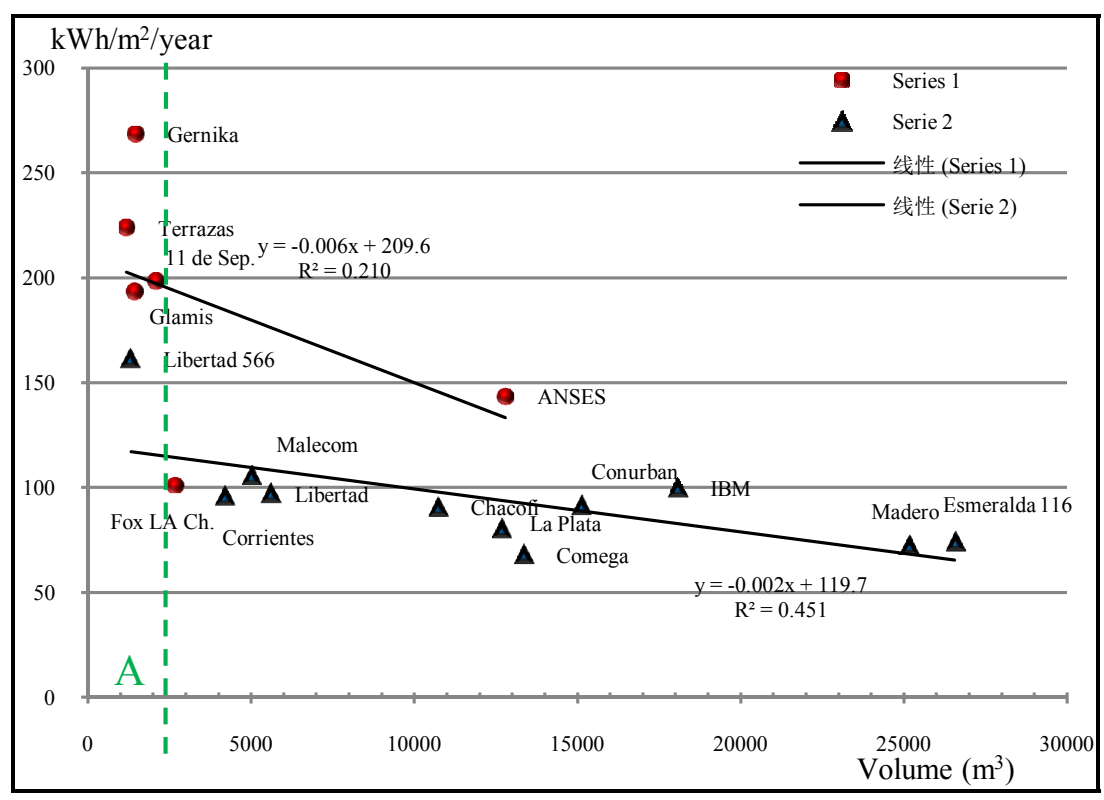

Figure 9. Heat load per square meter of the different analyzed buildings. Comparison with previous work.

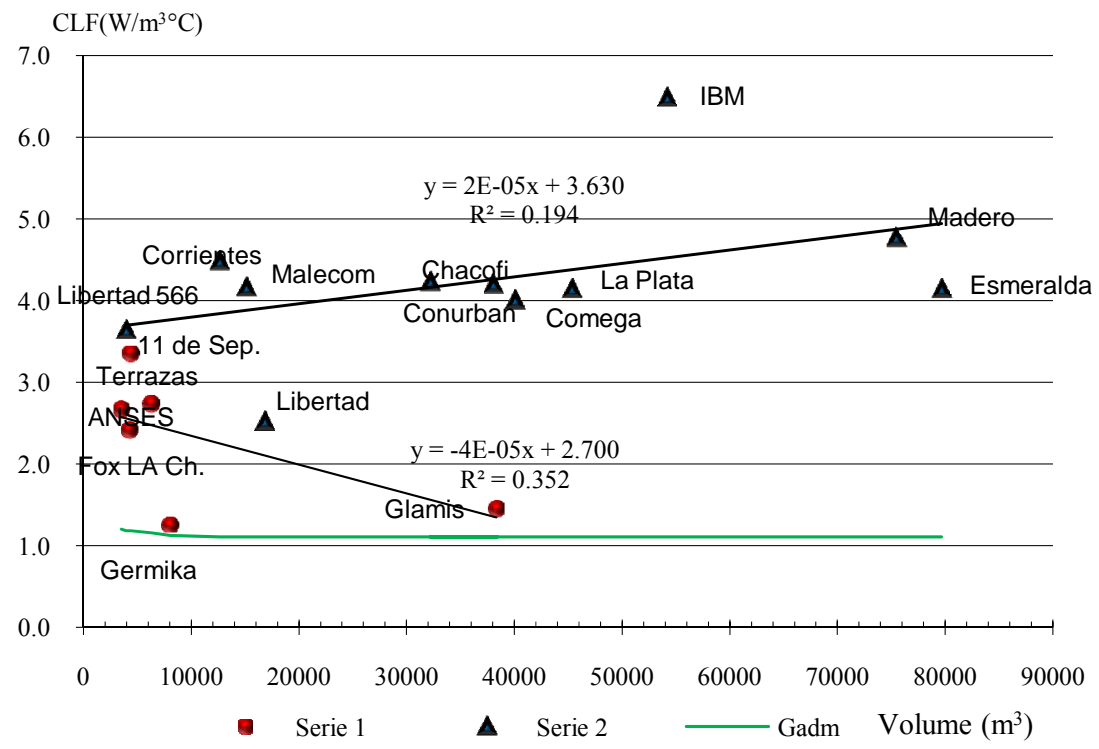

Figure 10. Relationship between the volume to be air-conditioned and $U$ value. Comparison with previous work.

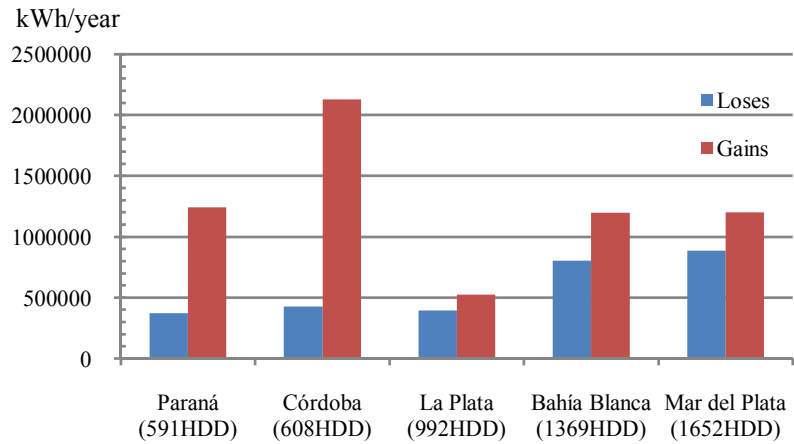

Figure 11. Heat losses and heat gains of Gernika building (Figure 6) in different cities of Argentina.

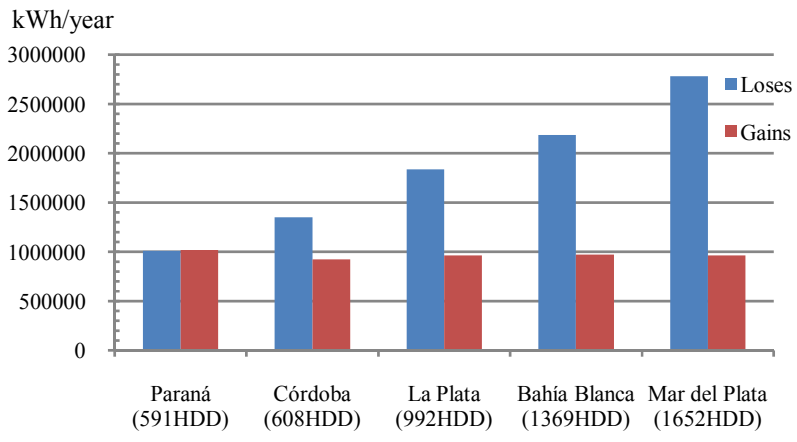

Figure 12. Heat losses and heat gains of ANSES building (Figure 4) in different cities of Argentina. 
teristics, but all within the temperate/mesothermal climate (Group C) [13]. It was interesting to observe the different results on heat losses and gain relationship which was obtained from the alleged location of the same instance in different cities of Argentina.

Additionally, the difference between buildings' $U L$ and admissible UL, determined by IRAM Standard 11,604 , leads us to think about the poor quality of buildings as regards energy efficiency. It should be noted that in all cases the $U L$ value is well above the admissible values by the rules.

With respect to indicators of energy efficiency in buildings, $U L$ coefficient is appropriate to characterize the thermal quality of buildings and enable comparisons, while the annual heat load per area unit can display the behavior they will have on the site they are deployed. IRAM standards provide admissible heat load values on cooling but there is still to incorporate this indicator for heating.

\section{Ackonwledgements}

This work was supported by Agencia Nacional de Promoción Científica y Tecnológica (ANPCyT), Consejo Nacional de Investigaciones Científicas y Técnicas (CONICET) and Universidad Nacional de La Plata (UNLP), Argentina. It was developed in LAyHS-FAUUNLP. It is framed within one of the main research lines developed in the laboratory, aimed at energy efficiency in building for urban areas. It is part of the objectives of PICT $06 \# 956$ "Energy efficiency in building for metropolitan areas" and of the project accredited by UNLP "Energy Efficiency and Sustainability for the materialization of Buildings in the Context of Climate Change Adaptation."

\section{REFERENCES}

[1] IPCC, "Tercer Informe de Evaluación del Intergovernmental Panel on Climate Change: Cambio Climático," Geneva, 2001.

[2] A. Vergara and J. De Las Rivas, Territorios Inteligentes. La Ciudad Sostenible," Fundación Metrópoli, Madrid, 2004.
[3] L. Perez-Lomnard, et al., "A Review on Buildings Energy Consumption Information," Journal Energy and Buildings, Vol. 40, No. 3, 2008, pp. 394-398.

[4] B. Edwards, "Guía Básica de la Sostenibilidad," Gustavo Gili, 2008

[5] Secretaría de Energía de la Nación, "Informe de Auditoría de Gestión del Programa de Políticas Energéticas," Ministerio de Planificación Federal Inversión Pública y Servicios, Buenos Aires, 2008.

[6] J. Kneifel, "Life-cycle Carbon and Cost Analysis of Energy Efficiency Measures in New Commercial Buildings," Journal Energy and Buildings, Vol. 42, No. 3, 2010, pp. 333-340.

[7] J. F. Liernur, "Voz 'Torre'," Diccionario de Arquitectura en la Argentina, Editorial Clarín, Buenos Aires, 2004.

[8] E. Rosenfeld and J. Czajkowski, "Catálogo de Tipologías de Viviendas Urbanas en el Área Metropolitana de Buenos Aires," Su Funcionamiento Energético y Bioclimático, IDEHAB-FAU-UNLP, La Plata, 1992.

[9] IRAM 11659-2, “Aislamiento Térmico de Edificios. Verificación de sus Condiciones Higrotérmicas. Ahorro de Energía en Refrigeración. Parte 2: Viviendas," Instituto Argentino de Normalización y Certificación, Buenos Aires, 2007.

[10] IRAM 11604, “Aislamiento Térmico de Edificios. Verificación de sus Condiciones Higrotérmicas. Ahorro de Energía en Calefacción. Coeficiente Volumétrico G de Pérdidas de Calor. Cálculo y valores Límites," Instituto Argentino de Normalización y Certificación, Buenos Aires, 1990 (Under Review; 2013).

[11] C. Corredera and J. Czajkowski, "Evolución en el Diseño de Torres de Oficinas en la Argentina Desde un Enfoque Ambiental," ENCAC, Curitiba, 2003.

[12] J. Czajkowski, et al., "EnergoCAD. Sistema Informatizado Para el Diseño Bioclimático de Alternativas Edilicias," 15a Reunión de ASADES, Catamarca, 1992.

[13] M. C. Peel, et al., "Updated World Map of the KöppenGeiger Climate Classification," Hydrology and Earth System Sciences, Vol. 11, No. 5, 2007, pp. 1633-1644. http://www.hydrol-earth-syst-sci.net/11/1633/2007/hess-1 1-1633-2007.html 